\title{
Silsesquioxanes as Precursors to Ceramic Composites
}

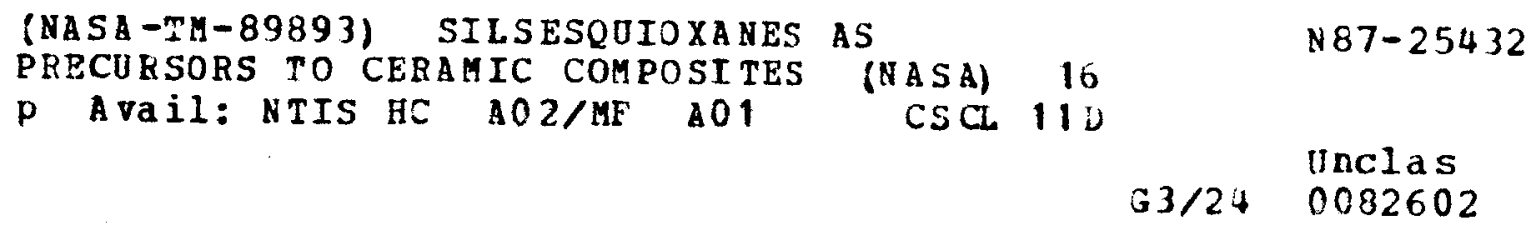

Frances I. Hurwitz

Lewis Research Center

Cleveland, Ohio

and

Lizbeth H. Hyatt, Joy Gorecki, and Lisa D'Amore

Case Western Reserve University

Cleveland, Ohio

Prepared for the

11th Annual Conference on Composites, Advanced Ceramics, and Composite Materials

cosponsored by the American Ceramic Society, DOD, and NASA Cocoa Beach, Florida, January 18-23, 1987

\section{NMSA}




\title{
SILSESQUIOXANES AS PRECURSORS TO CERAMIC COMPOSITES
}

\author{
Frances I. Hurwitz \\ National Aeronautics and Space Administration \\ Lewis Research Center \\ Cleveland, Ohio 44135 \\ Lizbeth H. Hyatt \\ Case Western Reserve University \\ Department of Chemical Engineering \\ Cleveland, Ohto 44106 \\ Joy Gorecki* \\ Case Western Reserve University \\ Department of Macromolecular Science \\ Cleveland, Ohio 44106 \\ and \\ Lisa D'Amoret \\ Case Western Reserve University \\ Department of Chemical Engineering \\ Cleveland, Ohio 44106
}

SUMMARY

Silsesquioxanes having the general structure RSi0 1.5 , where $R=$ methy 1 , propy 1 , or pheny 1 , melt flow at 70 to $100{ }^{\circ} \mathrm{C}$. Above $100^{\circ} \mathrm{C}$, free $-\mathrm{OH}$ groups condense. At $225^{\circ} \mathrm{C}$ further crosslinking occurs, and the materials form thermosets. Pyrolysis, with accompanying loss of volatiles, takes place at nominally $525{ }^{\circ} \mathrm{C}$. At higher temperatures, the $\mathrm{R}$ group serves as an internal carbon source for carbothermal reduction to SiC accompanied by the evolution of $C 0$. By blending silsesquioxanes with varying $R$ groups, both the melt rheology and composition of the fired ceramic can be controlled. Fibers can be spun from the melt which are stable in argon to $1400^{\circ} \mathrm{C}$. The silsesquioxanes also have been used as matrix precursors for Nicalon and a-SiC platelet reinforced composites.

\section{INTRODUCTION}

Utilization of polymeric precursors to ceramic fibers and ceramic matrix composites offers ease of processing at low temperatures, and the opportunity to produce small diameter, continuous fibers and complex-shaped, flaw tolerant, ceramic composite parts.

Polysilsesquioxane gels having the general formula (RSi0 1.5 ) n have been used to produce SiC powders (refs. 1 and 2). Since the carbon is covalently bonded to the silicon, the ratio of $\mathrm{C} / \mathrm{Si}$ in the starting material, the extent

* Summer Student Intern at NASA Lewis Research Center.

tSummer Student at NASA Lewis sponsored by the Society of Women Engineers. 
of crosslinking and the pyrolysis conditions determine the yield and properties of the resulting powders.

Proposed polysilsesquioxane structures are shown in figure 1 . It is presumed that the unordered structure is the more common, but that lower molecular weight molecules, particularly those with $R=$ pheny 1 , may adopt the ladder conformation (ref. 3). The nature of the $R$ group and molecular structure of the gel also influence the rheological behavior of the silsesquioxanes. Hence, by modifying the starting composition and crosslinked structure, and by forming copolymers, conditions sultable for processing both small diameter fibers and forming composite matrices can be determined.

The composition of the final ceramic will be determined by the stoichiometry of the polymer or copolymer, which may undergo several reactions prior to reaching a temperature at which carbothermal reduction can occur. Ideally, a C/Si ratio of $5 / 2$ at the onset of the carbothermal reduction should yield stoichiometric SiC. However, deviations from this ratio would be expected to produce other products, including excess carbon, $\mathrm{SiO}_{2}$, and $\mathrm{SiO}$ in route to the final ceramic (fig. 2).

This work focuses on demonstrating the feasibility of silsesquioxanes as potential precursors to both small diameter fibers and ceramic matrices for continuous fiber composites.

The $R$ groups of the polymers studied included methy 1 , propy 1 , phenyl, and vinyl, as well as copolymers of these. Composites reinforced with Nicalon fiber were fabricated and characterized by optical microscopy, scanning electron microscopy (SEM), TGA, differential thermal analysis (DTA), and dilatometry (TMA). Fibers were studied by SEM.

Experimental polymethy 1-, polyphenylpropy 1-, polypheny1-, and polypheny 1vinylsilsequioxanes were purchased from Petrarch Systems, Bristol, PA. Nicalon fiber, a product of Nippon Carbon, Tokyo, was obtained from Dow Corning, Midland, ML. The SiC platelets are a product of American Matrix, Inc., Knoxville, TN.

The polysilsesquioxanes were characterized by thermogravimetric analysis (TGA), microdielectrometry, Fourier transform infrared (FTIR) spectroscopy, and physical observation. TGA studies were carried out at several heating rates using a Perkin-Elmer TGS-2 on both as-received samples and Nicalon/ silsesquioxane composites.

Dielectric monitoring was conducted using a Micromet Eumetric System II. Polysilsesquioxane powders were melted onto the dielectric sensor to obtain good wetting, and the sensor and sample then heated in a DSC cell. Measurements were obtained simultaneously at $1,10,100,1000$, and $10000 \mathrm{~Hz}$. FTIR spectra were obtained on films cast from tetrahydrofuran onto KBr discs using a Perkin Elmer 1700 spectrophotmeter with double precision software at a resolution of $4 \mathrm{~cm}^{-1}$. Films held between two $\mathrm{KBr}$ discs were heated in-situ and the spectra ratioed to $\mathrm{KBr}$ at the same temperature.

Fibers were hand drawn from the polysilsesquioxane melt maintained at a temperature of 120 to $130^{\circ} \mathrm{C}$. They were then exposed to ultraviolet light at 
$254 \mathrm{~nm}$ and a power density of 12 to $15 \mathrm{~mW} / \mathrm{cm}^{2}$ for periods of 2 to $25 \mathrm{hr}$. Irradiated fibers were heated from 0 to $225^{\circ} \mathrm{C}$ at $3{ }^{\circ} \mathrm{C} / \mathrm{min}$, and held at $225^{\circ} \mathrm{C}$ for $3 \mathrm{hr}$. The temperature then was increased at $3^{\circ} \mathrm{C} / \mathrm{min}$ to 1000,1200 , or $1400{ }^{\circ} \mathrm{C}$. Fibers were heated in an argon or nitrogen atmosphere, and characterized by scanning electron microscopy (SEM).

Composites were fabricated by winding Nicalon fiber at 14 turns/cm on a mandrel, and coating the fiber with the polysilsesquioxane melt at a temperature of nominally $150^{\circ} \mathrm{C}$. A commerclal silicone glycol surfactant, Dow Corning A57, was added to some resin batches to increase flow. Addition of A57 was at a ratio of $3.75 \mathrm{ml}$ additive per $50 \mathrm{gm}$ of polysilsesquioxane powder. The prepreg was removed from the mandrel, cut and stacked 10 plies high in a matched metal die mold. The mold was inserted into a cold press. Contact pressure was applied and press temperature was increased to $150^{\circ} \mathrm{C}$; these conditions were maintained for $3 \mathrm{hr}$. The temperature was increased to $225{ }^{\circ} \mathrm{C}, 689 \mathrm{~Pa}$ pressure applied, and temperature and pressure maintained for $90 \mathrm{~min}$. Composites were pyrolyzed in air at $525{ }^{\circ} \mathrm{C}$ for $2 \mathrm{hr}$. Pyrolyzed composites were heated at $3{ }^{\circ} \mathrm{C} / \mathrm{min}$ to 1000,1200 or $1400{ }^{\circ} \mathrm{C}$ in flowing argon.

Platelet reinforced composites were formed by mixing the platelets with the dry ground polysilsesquioxane powders and hot pressing. Platelets were added at a ratio of $7.88 \mathrm{gm}$ per $6.24 \mathrm{gm}$ powder, nominally 50 vol 7 .

Composites were characterized by optical microscopy, SEM and energy dispersive spectroscopy (EDS), wavelength dispersive spectroscopy (WDS), and thermal expansion.

\section{RESULTS AND DISCUSSION}

\section{Polysilsesquioxanes}

Four polysilsesquioxanes were screened initially: polymethyl-, polyphenylpropy 1-, polypheny 1-, and polyphenylvinylsilsesquioxane. of these, the polymethyl and polyphenylpropyl exhibited superior rheological behavior; these were studied both individually and as copolymer blends. The as-received phenylpropyl copolymer contains seven phenyl groups to three propyl, and was blended with the methyl polymer to produce an initial C/Si ratio of nominally $5 / 2$, denoted as Batch 2. The Batch 1 material contained a slightly higher initial concentration of phenyl groups.

Weight change as a function of temperature for both batches obtained at a heating rate of $5{ }^{\circ} \mathrm{C} / \mathrm{min}$ in nitrogen is shown in figure 3 . Between ambient temperature and $1000{ }^{\circ} \mathrm{C}$ weight transitions are observed at approximately 200 and $525^{\circ} \mathrm{C}$, with a possible third, smaller change at nominally $750{ }^{\circ} \mathrm{C}$. The first of these is more pronounced for the higher methyl composition.

Infrared spectra of thin films heated between $\mathrm{KBr}$ discs were obtained to characterize the lower temperature region $\left(23\right.$ to $\left.235^{\circ} \mathrm{C}\right)$. The FTIR spectra of polyphenylpropylsilsesquioxane are shown in figure 4. The as-received materials exhibit an $\mathrm{H}$-bonded $\mathrm{OH}$ stretch between 3600 and $3200 \mathrm{~cm}^{-1}$, as well as a sllanol peak at 943 to $835 \mathrm{~cm}^{-1}$. which both disappear on heating to $150{ }^{\circ} \mathrm{C}$. The Si-0-Si peak in the 1240 to $955 \mathrm{~cm}^{-1}$ region, comprised of several overlapping bands, exhibits an overall increase in intensity, with more substantial 
increases at 1106 and $1035 \mathrm{~cm}^{-1}$, possibly characteristic of the development of a more ordered, ladder polymer. The spectral behavior of polymethylsilsesquioxane was similar to the phenylpropyl. The spectra of polyphenyisilsesquioxane, by comparison ( $\mathrm{fig} .5$ ), has a distinct band at $1035 \mathrm{~cm}^{-1}$, probably characteristic of a greater degree of ladder polymer, and shows only minor changes in band shape on heating to $235^{\circ} \mathrm{C}$. No residual silanol groups were observed.

Comparisons of figures 3 and 4 show that the silanol condensation does not contribute significantly to any weight change, while the TGA transition at $200{ }^{\circ} \mathrm{C}$ is accompanied by changes in the $\mathrm{Si-O}-\mathrm{Si}$ structure.

Monitoring resistivity (conductivity-1) (ref. 4) (fig. 6) for the mixed polysilsesquioxanes (Batch 2) shows that as the temperature is increased from ambient to $225^{\circ} \mathrm{C}$, then held at $225^{\circ} \mathrm{C}$ for $2 \mathrm{hr}$, the resistivity initially decreases with temperature, corresponding to a decrease in viscosity, then increases as the polymer cures, undergoing a thermoset type of crossinking. (At this stage the polymer does not reme1t.) An expanded plot of the initial 30 min of the reaction is shown in figure 7 . The physical observation of bolling of the polymer blend at $180{ }^{\circ} \mathrm{C}$ corresponds to the onset of the first TGA transition (fig. 3). The point on the curve labelled "flow" corresponds to a viscosity empirically found suitable for fiber impregnation, while that indicated as "fibers" was appropriate for fiber formation.

\section{Fibers}

Fibers 30 to $40 \mu \mathrm{m}$ in diameter were hand drawn from the polysilsesquioxane melt in lengths from 4 to $8 \mathrm{ft}$, at a temperature of 120 to $130^{\circ} \mathrm{C}$. As drawn fibers will remelt on further heating, the polysilsesquioxanes crossilink on uv irradiation at $254 \mathrm{~nm}$; however, the extinction coefficient is high, so that crosslinking occurs on the surface and not throughout the bulk of the fiber.

Fibers irradiated for 3 and $25 \mathrm{hr}$ are shown in figure 8 . Following uv exposure, the tip of the fiber was touched against a hot plate, remelting the noncrosslinked bulk polymer, and revealing a crosslinked shell which does not melt. At $3 \mathrm{hr}$ (fig. $8(\mathrm{a})$ ) this shell is quite thin $(<2 \mu \mathrm{m})$. As exposure time is increased, this crosslinked material shrinks relative to the bulk of the fiber, splitting the fiber (fig. 8(b)). Hence, the entire fiber cannot be crosslinked by uv irradiation. However, once even a thin crossinked shell has been formed, the fiber can be heated to $225^{\circ} \mathrm{C}$ and the fiber bulk crosslinked thermally, as shown by the dielectric changes in the polymer which occur at this temperature (fig. 6). Once the bulk of the fiber has undergone crosslinking, the fibers can be heated further without losing their shape. Fibers heated to 1000,1200 , and $1400{ }^{\circ} \mathrm{C}$ in argon and fractured by hand are shown in figure 9. Uv exposure was decreased to as little as $2 \mathrm{hr}$ in some cases without affecting the fibers' ability to survive to high temperatures.

\section{Composites}

Nicalon/silsesquioxane composites are shown as hot pressed in figure 10. The resin exhibits good flow into the fiber tow, producing. few voids. Thermal expansion measurements made as the hot pressed composite is heated further 
(fig. 11) show a region of rapid expansion between 100 to $200{ }^{\circ} \mathrm{C}$. As the polymer matrix begins to cure, the expansion, whlle still positive, decreases in slope. Above $460^{\circ} \mathrm{C}$, as pyrolys is occurs, the composite shrinks, corresponding to the onset of weight loss. In unidirectional composites this shrinkage is accompanied by the formation of matrix cracks (fig. 12). Platelet reinforced composites did not exhibit the surface cracking observed for the Nicalon reinforced material. They did not undergo dimensional changes on pyrolysis, but developed more uniformly distributed matrix porosity (fig. 13).

Composites which were pyrolyzed at $525^{\circ} \mathrm{C}$ were subsequently heated at $3{ }^{\circ} \mathrm{C} / \mathrm{min}$ in argon to 1000,1200 , or $1400^{\circ} \mathrm{C}$, then fractured at room temperature in three point bending at a span to depth ratio of 32:1. Fracture surfaces are shown in figure 14. In the sample heated to $1000{ }^{\circ} \mathrm{C}(\mathrm{fig} .14(\mathrm{a}))$, fiber pullout is observed on the tensile surface, as is a shear failure at midplane. After heating to $1200^{\circ} \mathrm{C}$ (fig. $14(\mathrm{~b})$ ), faliure of fiber bundles, rather than individual fiber pullout, predominates. In the sample heated to $1400{ }^{\circ} \mathrm{C}$ (fig. $14(\mathrm{c})$ ), reaction between the fiber and the matrix appears to have occurred. The tensile and compressive surfaces are not readily distinguishable, and the fracture is characteristic of brittle fallure.

A piece of the Nicalon/silsesquioxane composite which had been heated to $1200{ }^{\circ} \mathrm{C}$ in argon was vacuum infiltrated with epoxy, polished, and examined by EDS to map stilicon and WDS to map carbon and oxygen. Results are shown in figure 15. The bright areas on the carbon map correspond to epoxy. Comparison of the matrix with the Nicalon fibers shows that the carbon content of both is comparable. The silicon content of the fibers is slightly greater than that of the matrix, while the oxygen content is slightly lower.

\section{CONCLUSIONS}

Polysilsesquioxanes show potential as precursors to both small diameter fibers and ceramic matrices. Modification of the polysilsesquioxane structure provides a means of controliing both the melt rheology and stoichiometry of the ceramic product. Low temperature processibility of both fibers and composites has been demonstrated.

Matrix cracking and shrinkage observed in unidirectional composites reinforced with Nicalon suggests the need to explore two- and three-dimensional weaves as opposed to crossply composite layup. Platelet reinforcement has demonstrated that large scale matrix cracking can be minimized or eliminated in favor of more uniformiy distributed matrix porosity.

\section{ACKNOWI_EDGMENTS}

The authors wish to thank Dave Hull, Ron Phillips, and Earl Hanes for their contributions to this work.

\section{REFERENCES}

1. D.A. White, S.M. Oleff, R.D. Boyer, P.A. Budinger, and J.R. Fox, "Preparation of Silicon Carbide from Organosilicon Gels: I, Synthes is and Characterization of Precursor Gels," Adv. Ceram. Mater., 2, 45-52 (1987). 
2. D.A. White, S.M. Oleff, and J.R. Fox, "Preparation of Silicon Carbide from Organosilicon Gels: II, Gel Pyrolysis and SiC Characterization," Adv. Ceram. Mater., 2., 53-59 (1987).

3. P.J. Launer, "Infrared Analys is of Organosilicon Compounds: SpectraStructure Correlations," pp. 77-79 in Silicon Compounds: Register and Review, Petrarch Systems, Bristol, PA, 1984.

4. D.R. Day, "Effects of Stoichiometric Mixing Ratio on Epoxy Cure - A Dielectric Analysis," Polym. Eng. Sci., 26, 362-366 (1986).

\section{SILSESQUIOXANES}

RSiO $_{1.5}$

$$
R=\text { methyl, propyl, vinyl, phenyl }
$$

T Resin

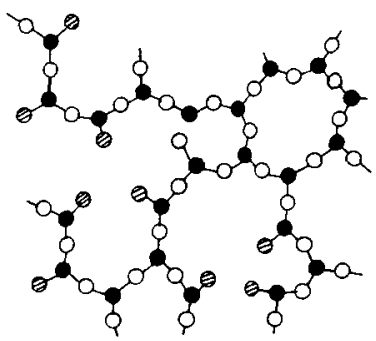

FIGURE 1. - STRUCTURE OF POLYSILSESQUIOXANES.
Ladder Polymer

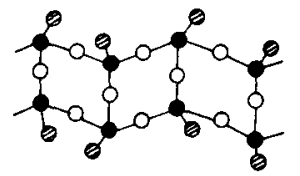

$\mathrm{SiO}_{1.5}+\mathrm{C}$ (deficient) $\longrightarrow \mathrm{SiC}+\mathrm{SiO}_{2}$

$+\mathrm{SiO} \uparrow+\mathrm{Co} \uparrow$

FIGURE 2. - POSSIBLE CARBOTHERMAL REDUCTION REACTIONS. 


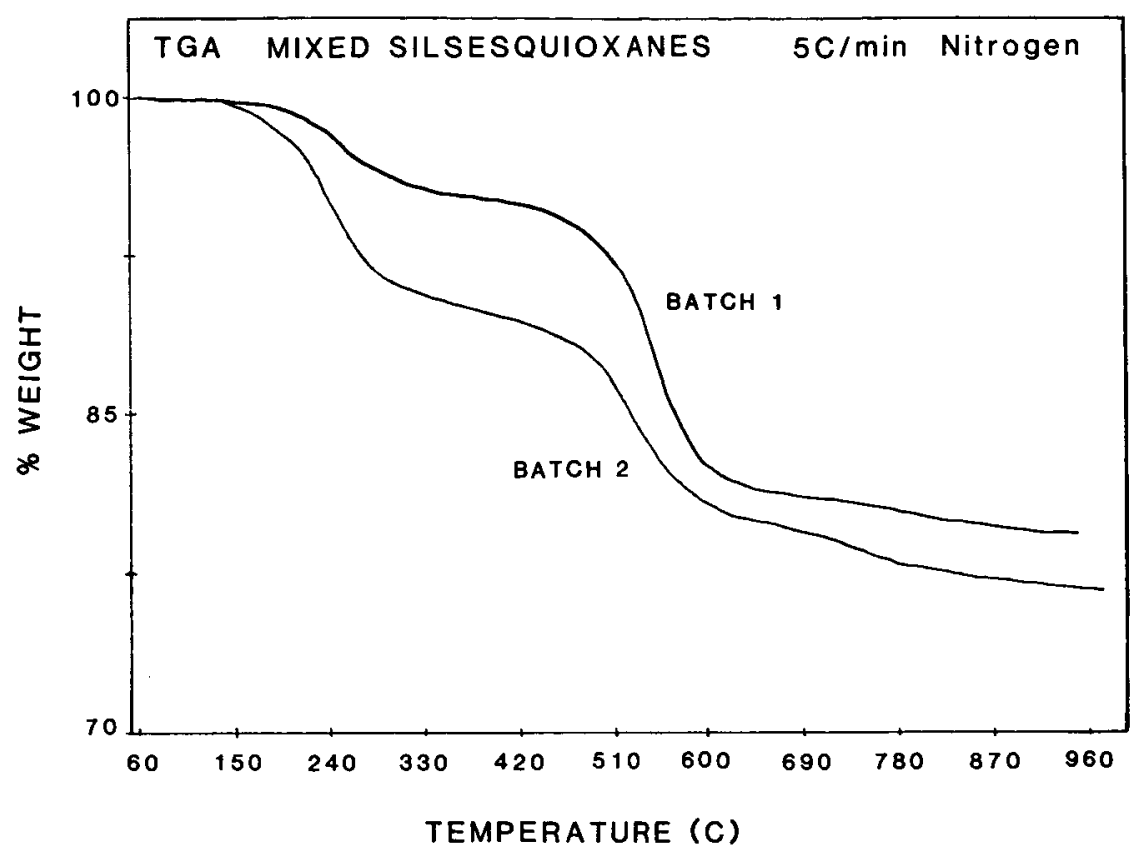

Figure 3. - TGA OF MIXED POLYSILSESQUiOXANES OBTAINED AT $5{ }^{\circ} \mathrm{C} /$ Min IN NITROGEN.

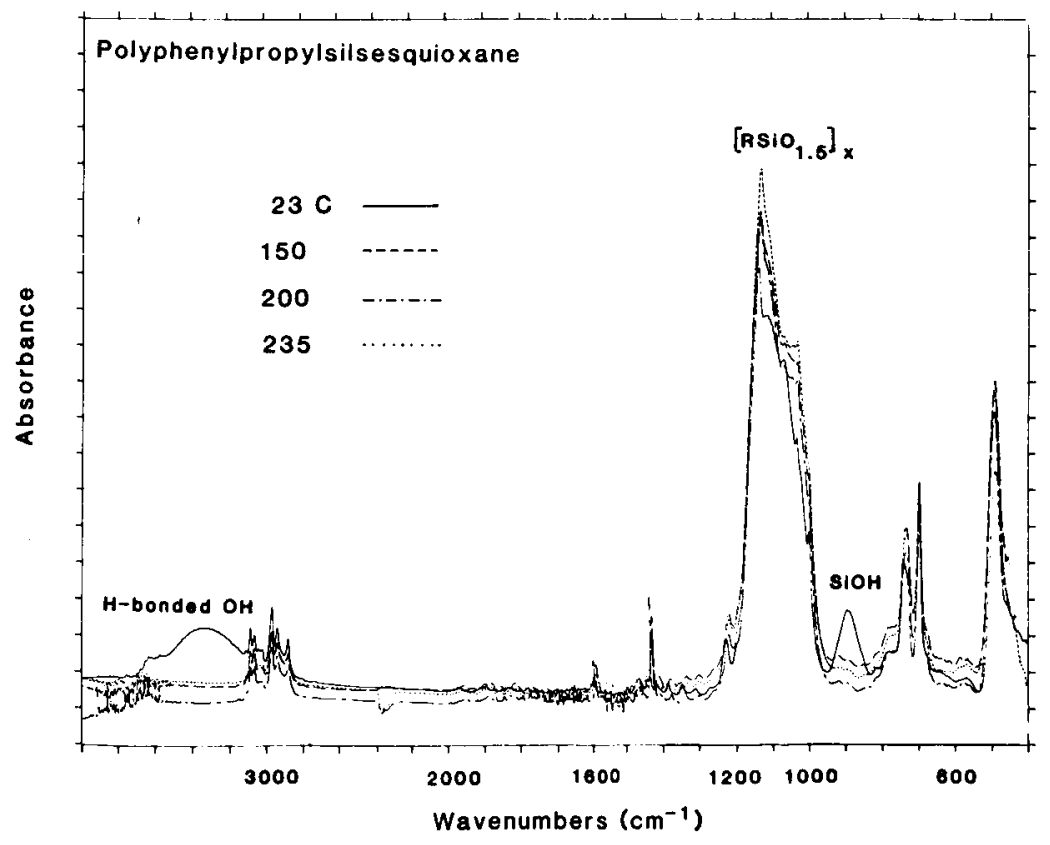

FIGURE 4. - FTIR SPECTRA OF POLYPHENYLPROPYLSILSESQUIOXANE. 


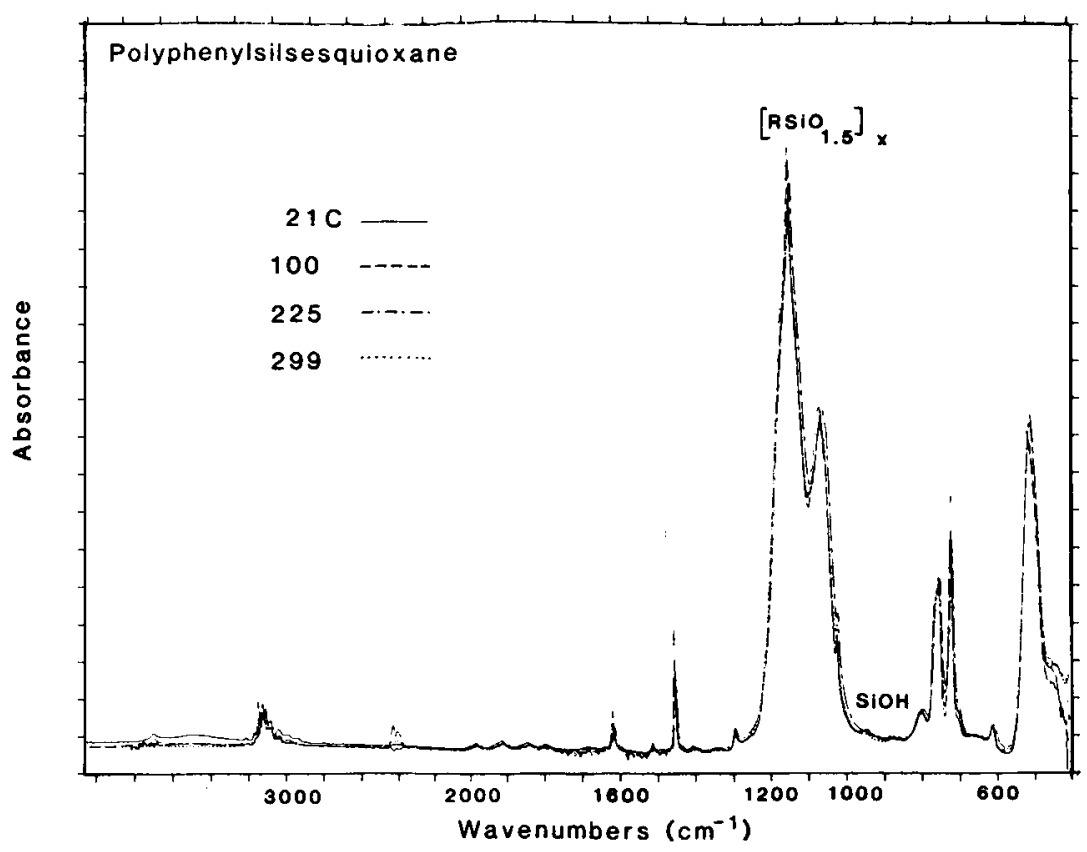

FIGURE 5. - FTIR SPECTRA OF POLYPHENYLSILSESQUIOXANE.

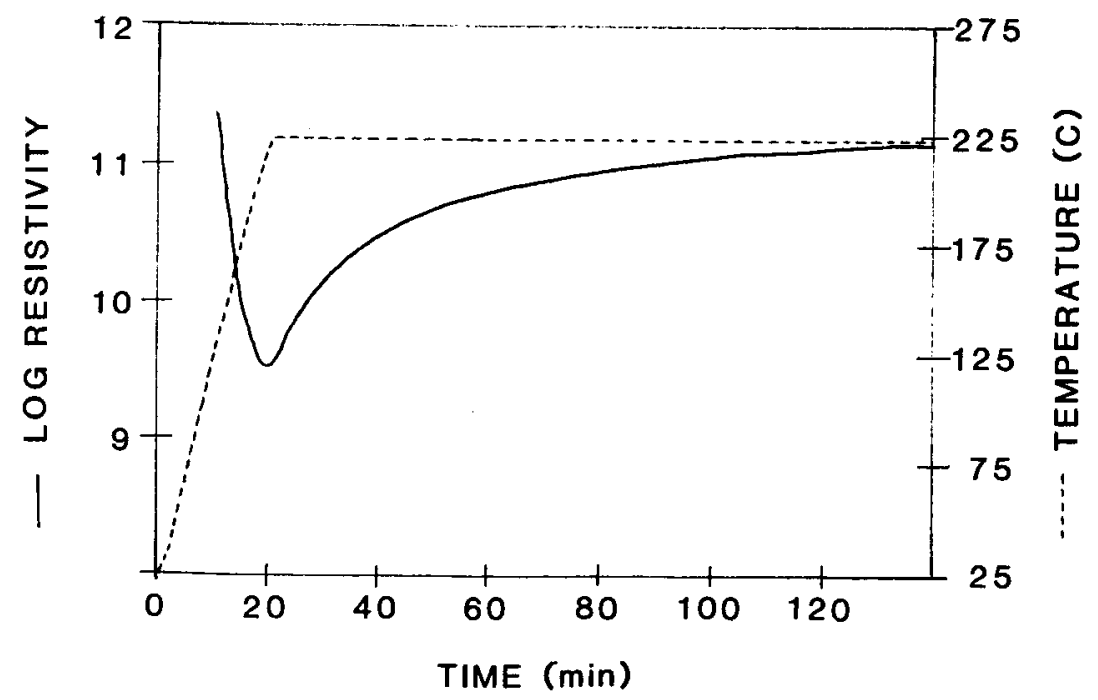

FIGURE 6. - RESISTIVITY OF MIXED POLYSILSESQUIOXANES AS TEMPERATURE IS INCREASED TO $225^{\circ} \mathrm{C}$ AND HELD FOR 2 HR. 


\section{ORCMA: PACE IS \\ OF POOR OJALITY}

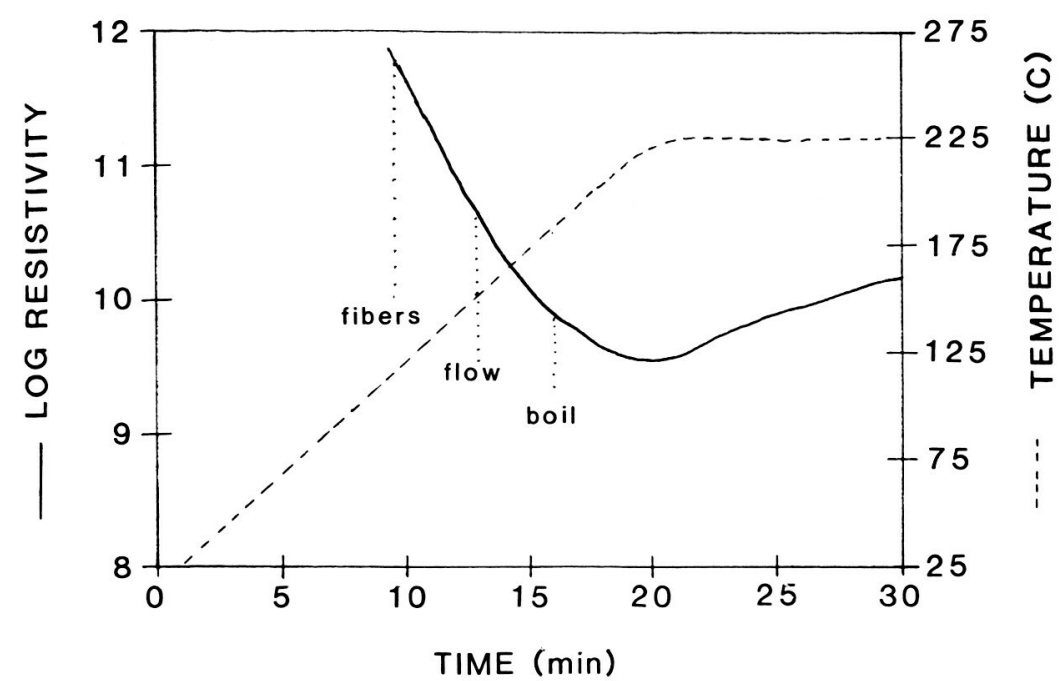

FIGURE 7. - RESISTIVITY OF MIXED POLYSILSESQUIOXANES DURING INITIAL 30 MIN OF CURE.
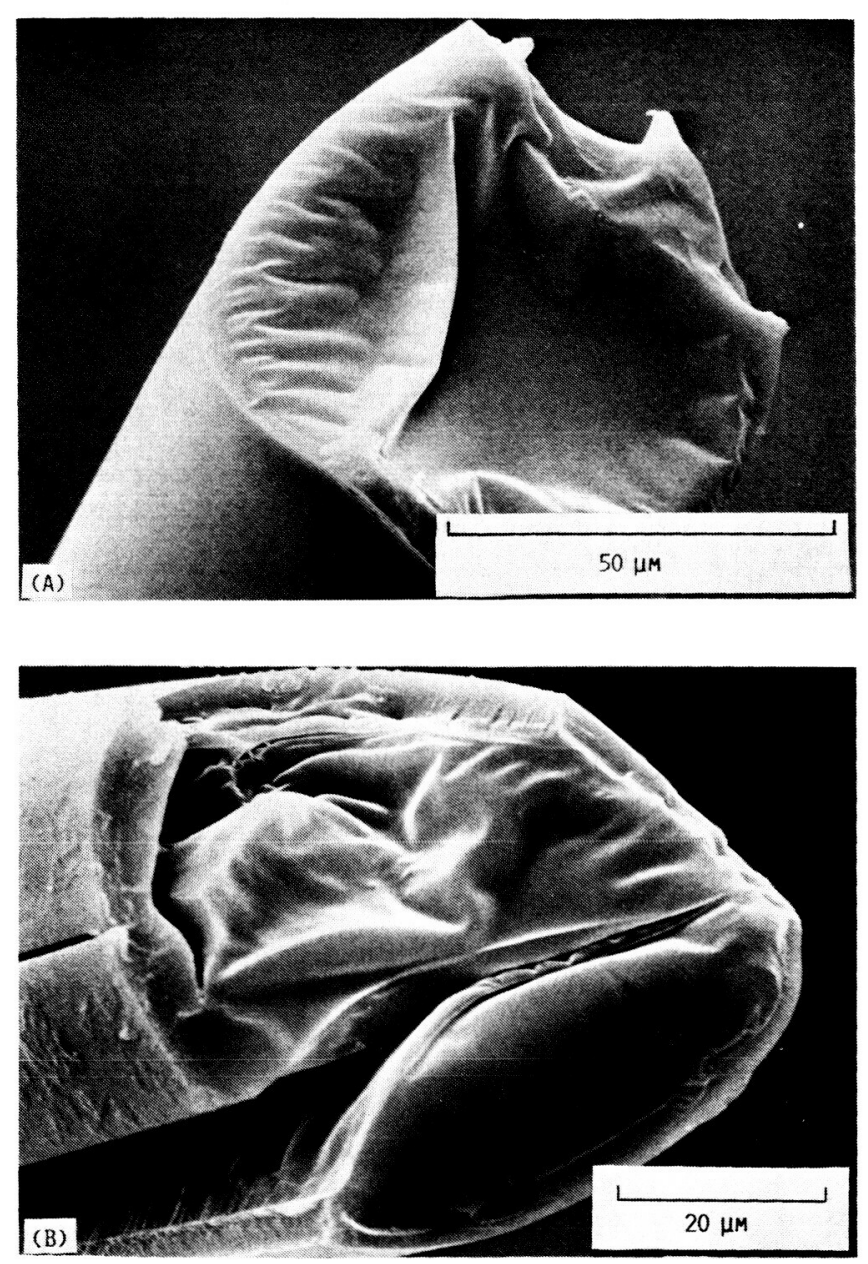

FIGURE 8. - POLYSILSEQUIOXANE FIBERS FOLLOWING UV EXPOSURE AT 254 mM FOR (A) 3 AND (B) $25 \mathrm{HR}$. 


\section{OR CRAL PAOE IS \\ OF POOR QUALITY}
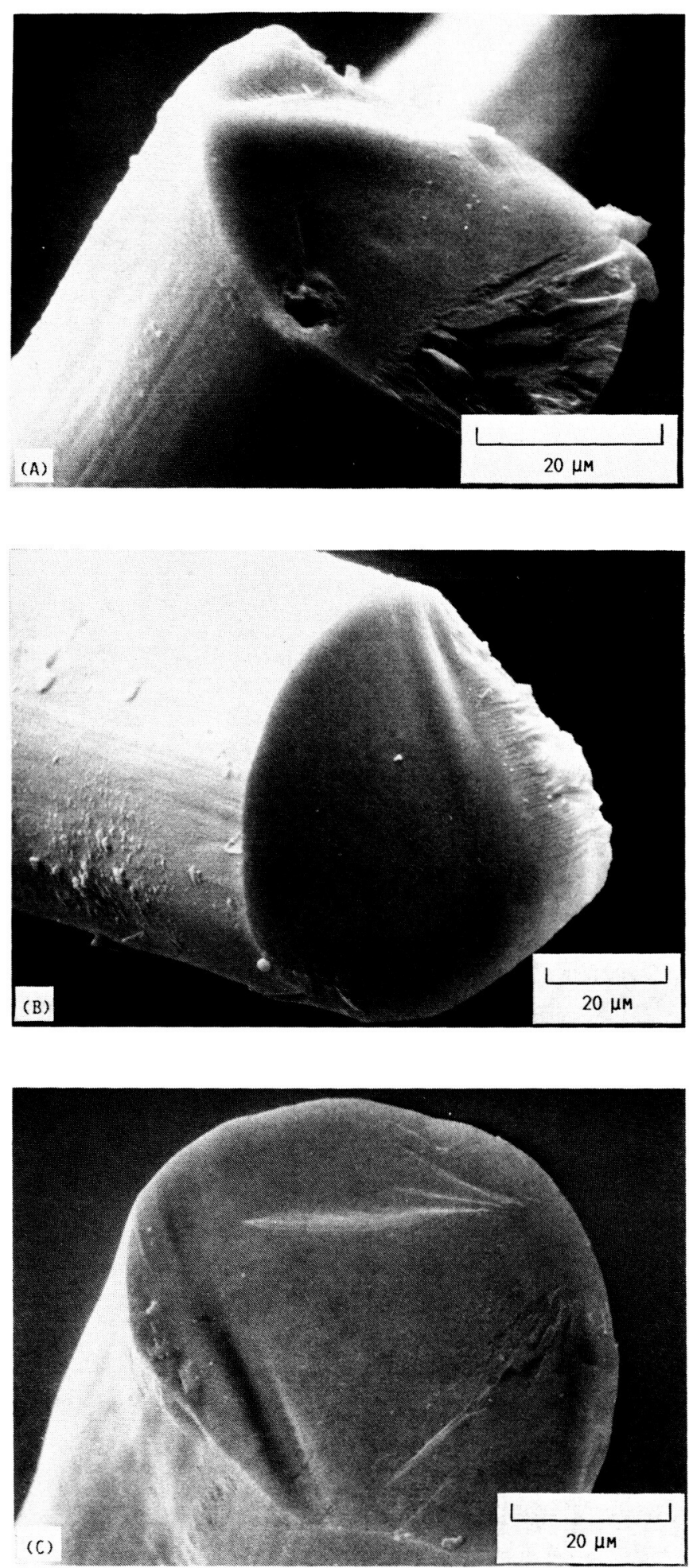

FIGURE 9. - POLYSILSESQUIOXANE FIBERS HEATED IN ARGON TO (A) 1000 , (B) 1200 , AND (C) $1400^{\circ} \mathrm{C}$. 


\section{CPChOP PAOE IS \\ OF POOR QUALITY}

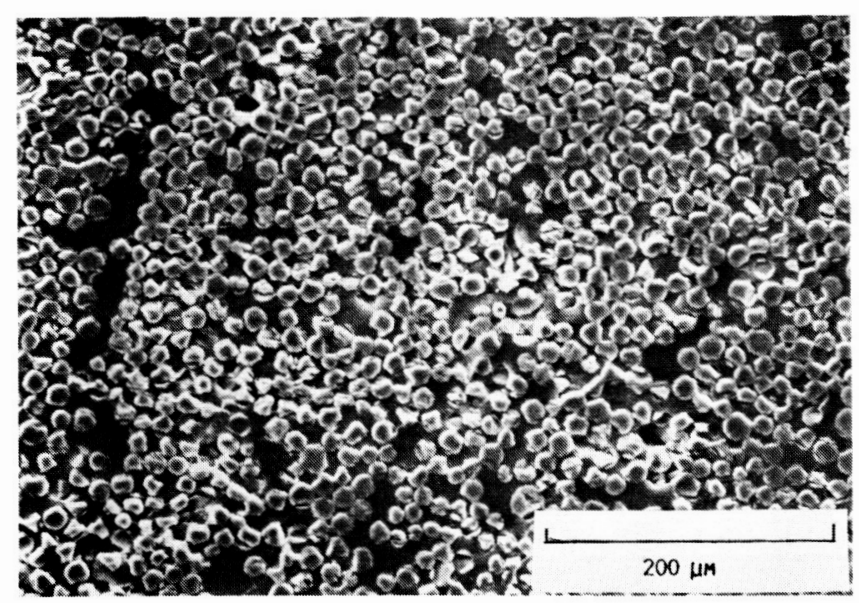

FIGURE 10. - AS HOT-PRESSED NICALON/SILSESOUIOXANE COMPOSITE.

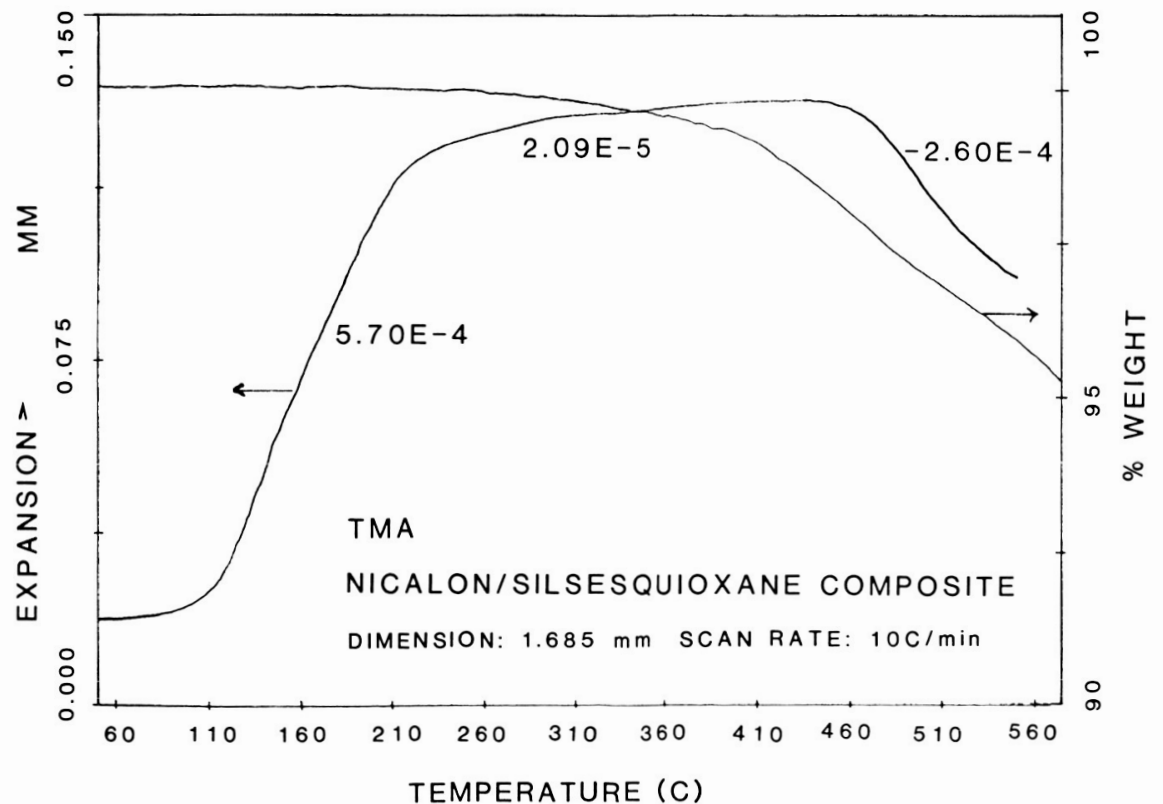

FIGURE 11. - THERMAL EXPANSION OF A NICALON/SILSESQUIOXANE COMPOSITE MEASURED THROUGH THE THICKNESS OF THE COMPOSITE. COEFFICIENTS OF EXPANSION ARE INDICATED FOR EACH REGION. WEIGHT CHANGE OF THE COMPOSITE WITH TEMPERATURE IS SUPERIMPOSED FOR COMPARISON. 

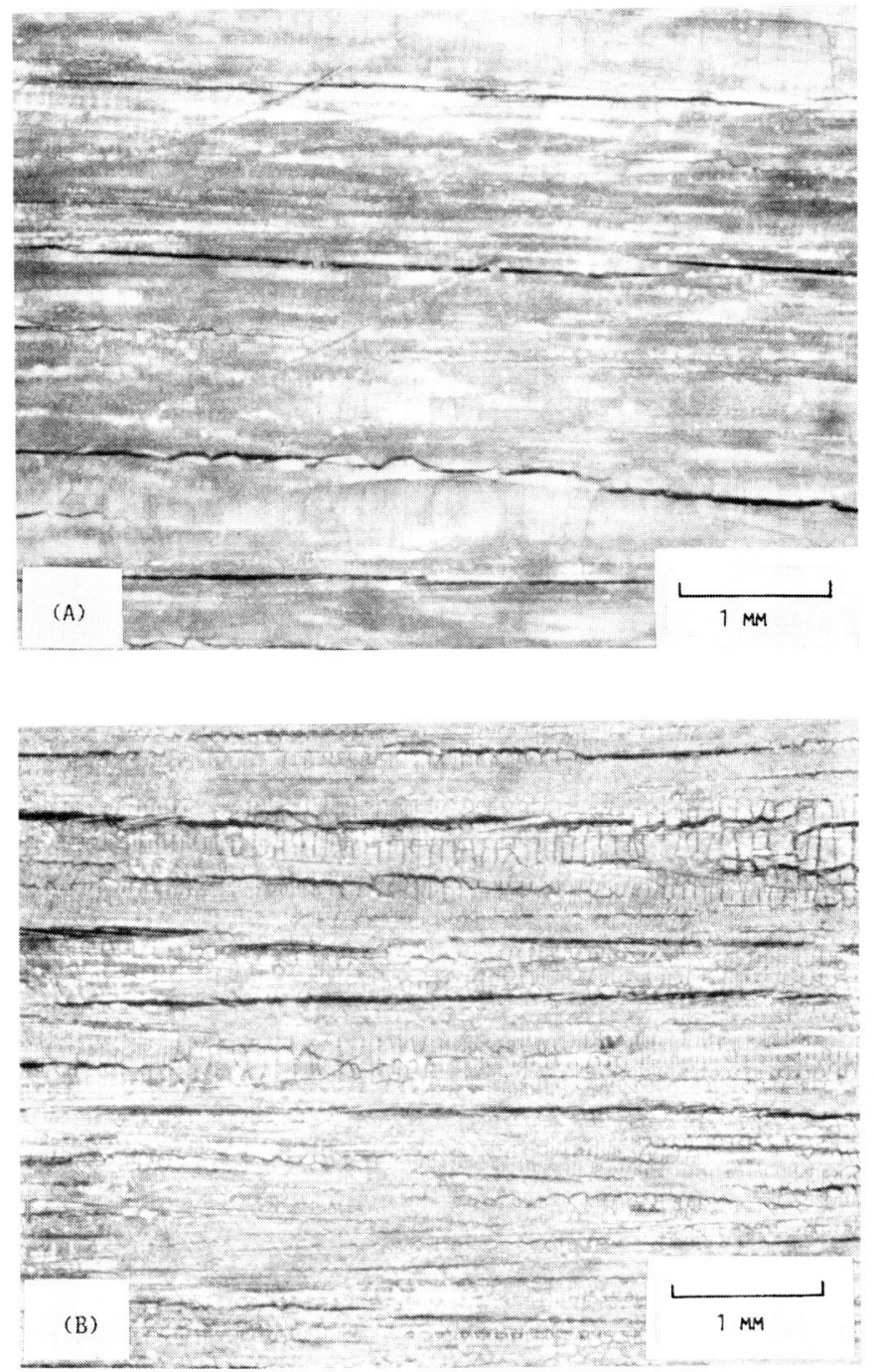

FIGURE 12. - COMPOSIIE SURFACES OF NICALON/SILSEQUIOXANE COMPOSITES (A) AFTER PYROLYSIS AT $525^{\circ} \mathrm{C}$ FOR 2 HR AND (B) FOLLOWING SUBSEQUENT HEATING TO $1000^{\circ} \mathrm{C}$.

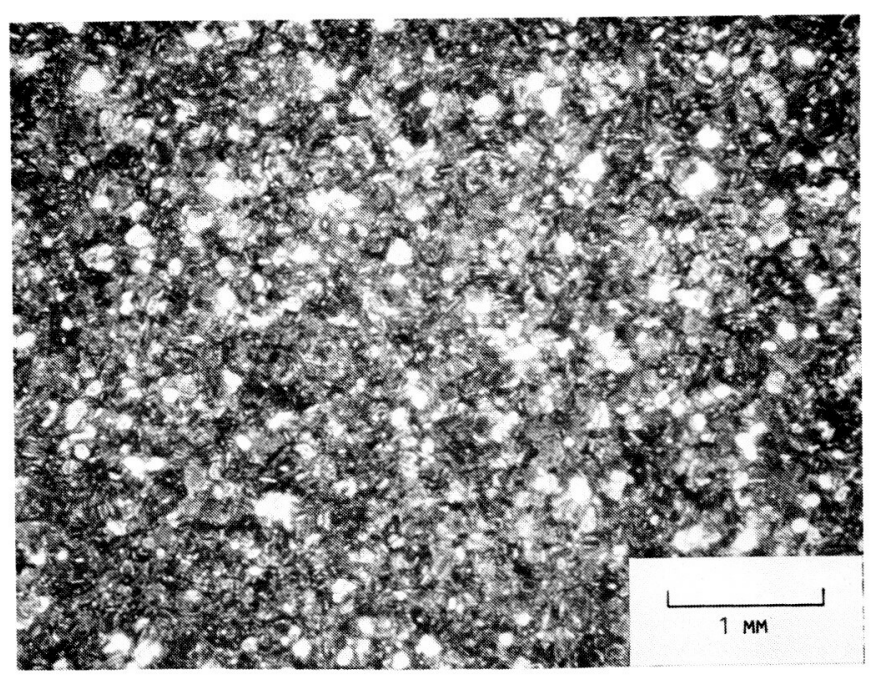

FIGURE 13 - PLAIELEI REINFORCED SILSESQUIOXANE COMPOSITE HEATED TO $1000{ }^{\circ} \mathrm{C}$.

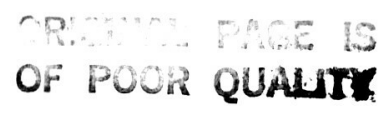




\section{ORICINAL PACE IS \\ OF POOR QUALITY}
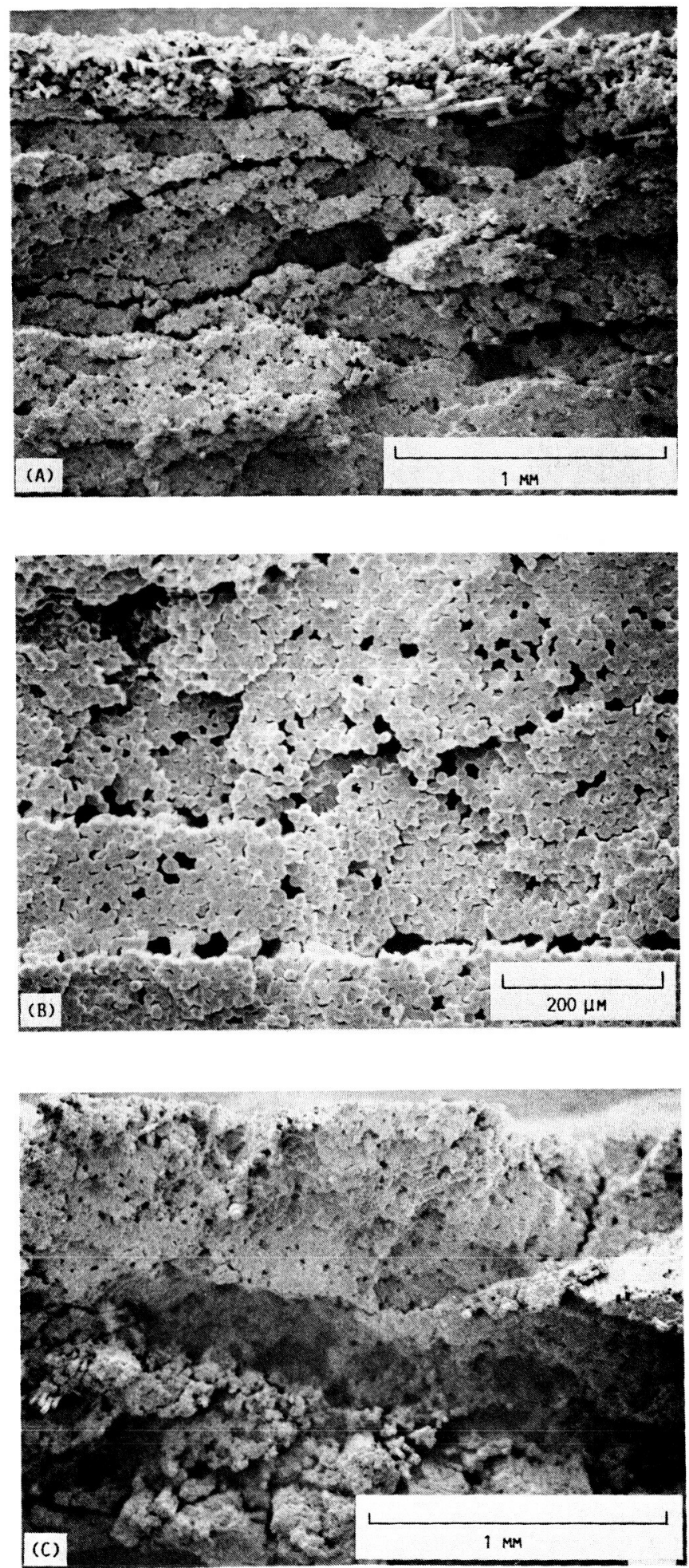

FIGURE 14. - FRACTURE SURFACES OF NICALON/SILSESQUIOXANE COMPOSITES HEATED TO (A) 1000 , (B) 1200 . AND (C) $1400{ }^{\circ} \mathrm{C}$, THEN FRACTURED AT ROOM TEMPERATURE IN THREE-POINT BENDING. 


\section{ORGMUAS PACE 15 \\ OF POOR QUALTY}
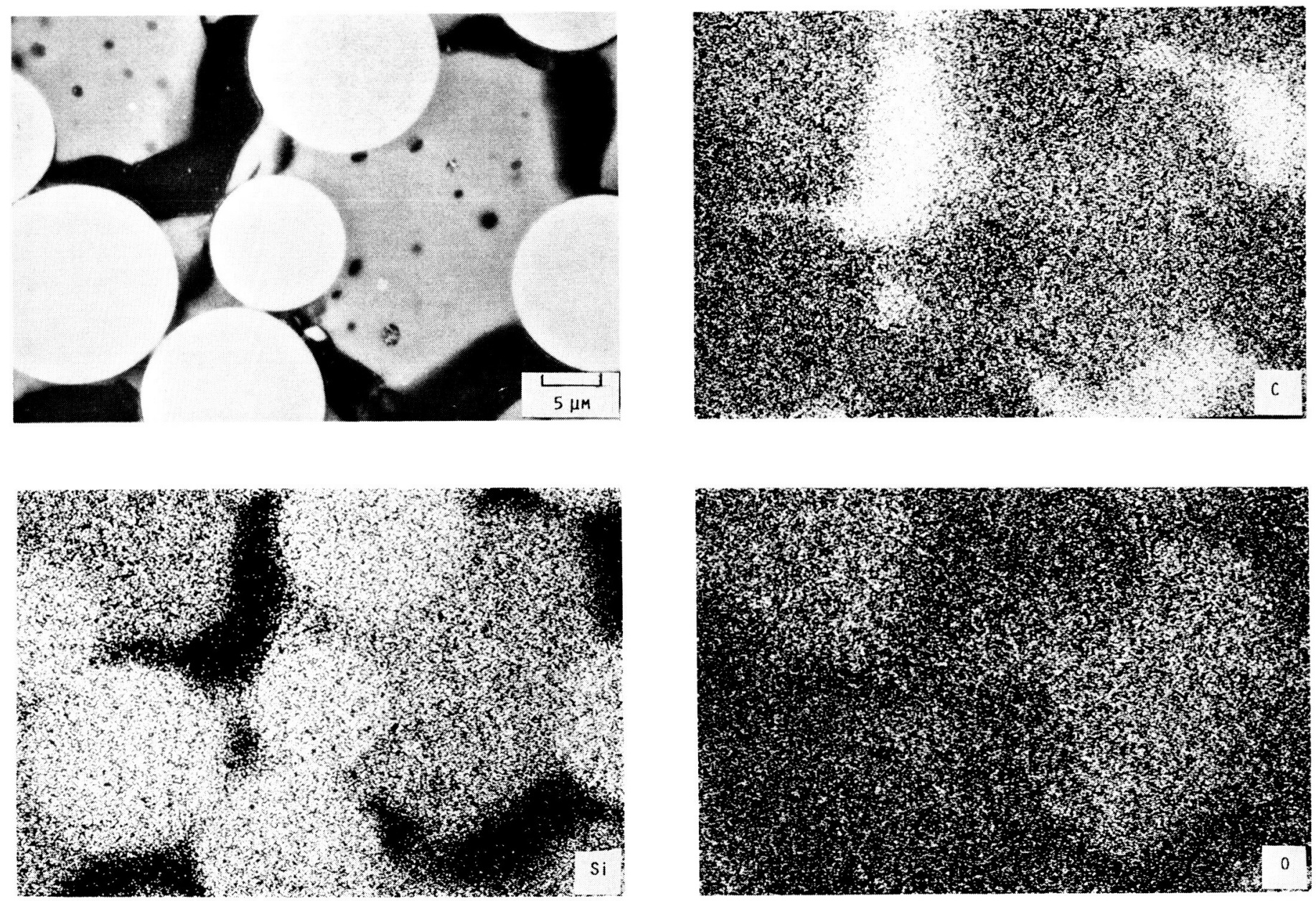

FIGURE 15. - ElEMENTAL COMPOSITION BASED ON EDS AND NDS OF NICALON/SILSESQUIOXANE COMPOSITE HEATED TO $1200{ }^{\circ} \mathrm{C}$ IN ARGON. 


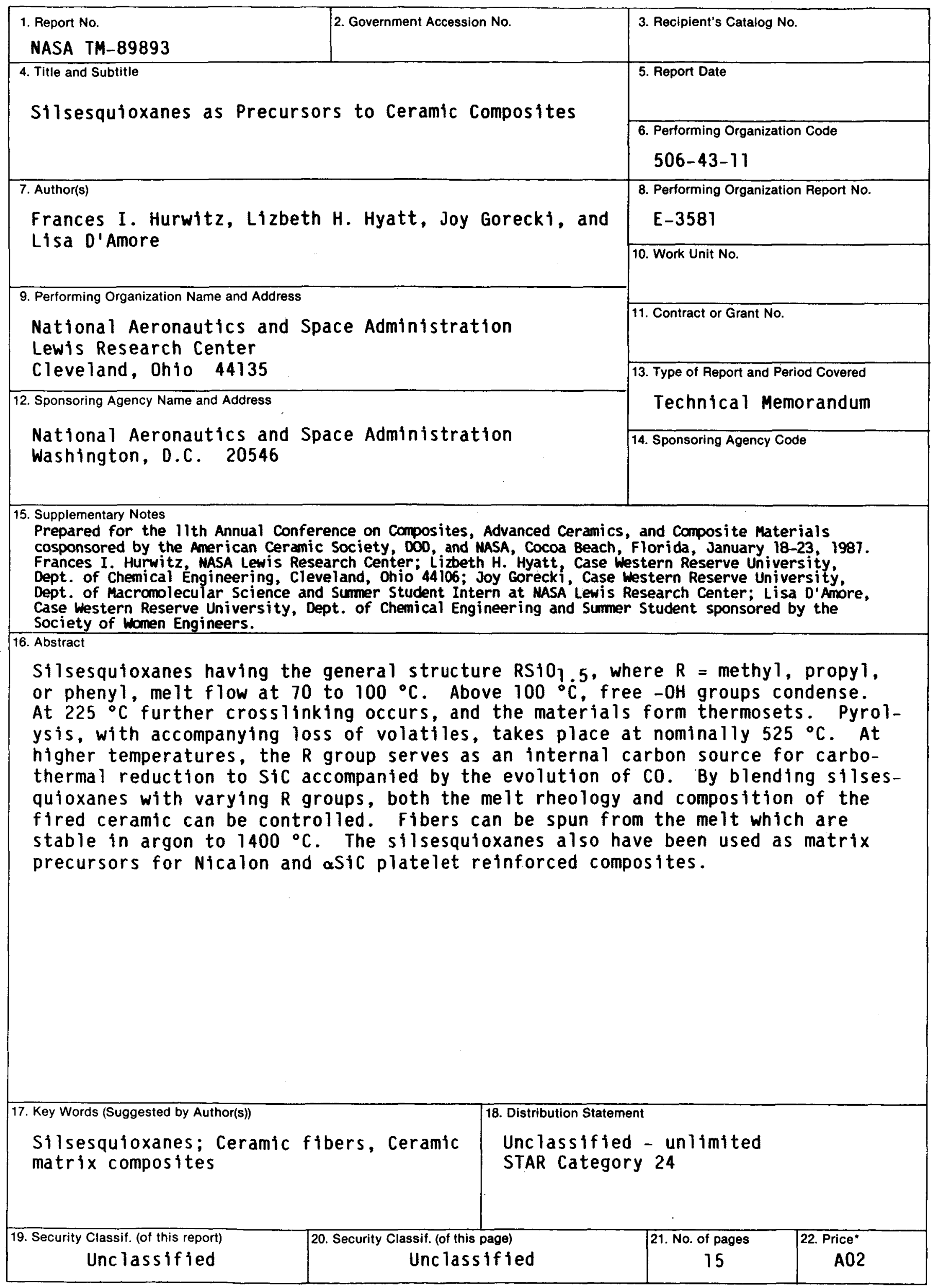

-For sale by the National Technical Information Service, Springfield, Virginia 22161 